\title{
Recombinant Human Erythropoietin Production in Chinese Hamster Ovary Cells Is Enhanced by Supplementation of $\alpha$-Helix Domain of 30Kc19 Protein
}

\author{
Hyeonjin Cha $(D)$ and Ju-Hyun Park * $D$
}

Citation: Cha, H.; Park, J.-H. Recombinant Human Erythropoietin Production in Chinese Hamster Ovary Cells Is Enhanced by Supplementation of $\alpha$-Helix Domain of 30Kc19 Protein. Appl. Sci. 2021, 11, 11009. https://doi.org/10.3390/ app112211009

Academic Editor: David Mills

Received: 19 October 2021

Accepted: 17 November 2021

Published: 20 November 2021

Publisher's Note: MDPI stays neutral with regard to jurisdictional claims in published maps and institutional affiliations.

Copyright: (c) 2021 by the authors. Licensee MDPI, Basel, Switzerland. This article is an open access article distributed under the terms and conditions of the Creative Commons Attribution (CC BY) license (https:// creativecommons.org/licenses/by/ $4.0 /)$.
Department of Biomedical Science, Kangwon National University, Chuncheon-si 24341, Gangwon-do, Korea; hyeon_j03@kangwon.ac.kr

* Correspondence: juhyunpark@kangwon.ac.kr; Tel.: +82-33-250-6566

\begin{abstract}
The enhancement of recombinant therapeutic protein production in mammalian cell culture has been regarded as an important issue in the biopharmaceutical industry. Previous studies have reported that the addition of the recombinant 30Kc19 protein, a silkworm-derived plasma protein with simultaneous cell-penetrating and mitochondrial enzyme-stabilizing properties, can enhance the recombinant protein expression in Chinese hamster ovary $(\mathrm{CHO})$ cell culture. Here, we produced an $\alpha$-helix N-terminal domain of $30 \mathrm{Kc} 19$, called $(30 \mathrm{Kc} 19 \alpha)$, and investigated its effects on the production of human erythropoietin (EPO), a widely used therapeutic protein for the treatment of anemia, in recombinant $\mathrm{CHO}$ cell culture. Similar to the full-length $30 \mathrm{Kc} 19,30 \mathrm{Kc} 19 \alpha$ was able to be mass-produced in a form of recombinant protein through an Escherichia coli expression system and delivered into EPO-producing $\mathrm{CHO}(\mathrm{EPO}-\mathrm{CHO})$ cells. Supplementing the medium of EPO-CHO cell culture with $30 \mathrm{Kc} 19 \alpha$ increased the intracellular $\mathrm{NADPH} / \mathrm{NADP}^{+}$ratio related to the flux of metabolic reducing power for protein biosynthesis, subsequently enhancing EPO production in serum-free culture. $30 \mathrm{Kc} 19 \alpha$ is considered to have certain advantages in the downstream purification process of therapeutic protein production when it is used as a medium supplement due to its small size and low isoelectric point compared to the full-length $30 \mathrm{Kc} 19$. These results suggest that $30 \mathrm{Kc} 19 \alpha$ has potential use for manufacturing biopharmaceutical proteins.
\end{abstract}

Keywords: 30Kc19 $\alpha$ protein; erythropoietin (EPO); Chinese hamster ovary (CHO) cell; biopharmaceuticals; productivity

\section{Introduction}

Human insulin, the world's first genetically engineered drug, was approved by the U.S. Food and Drug Administration in 1982. Since then, the market for biopharmaceuticals has grown dramatically [1,2]. Biopharmaceuticals are drug products synthesized or extracted from living organisms (including humans). Among them, recombinant therapeutic proteins such as monoclonal antibodies, hormones, vaccines, and enzymes occupy a large proportion [3,4]. The Chinese hamster ovary (CHO) cell line is a widely used mammalian cell line for the production of recombinant therapeutic proteins [5]. The wide use of the $\mathrm{CHO}$ cell system can be attributed to the following reasons: many previous cases of approvals from regulatory agencies, the availability of large-scale suspension culture using a chemically defined medium, and the presence of very effective transgene amplification methods such as the dihydrofolate reductase (DHFR)-mediated system [6]. In addition, recombinant proteins produced from $\mathrm{CHO}$ cells exhibit similar glycosylation profiles to original human proteins, which is an important advantage as a platform for the production of therapeutic proteins due to the correlation between the glycan structures of glycoproteins and in vivo activities [7-9]. To increase protein productivity in recombinant $\mathrm{CHO}$ cells, several strategies have been employed. To improve the time integral of viable cell concentration and/or the specific productivity of a foreign protein, the optimization of 
various culture conditions (such as $\mathrm{pH}$, dissolved oxygen and carbon dioxide, temperature, and osmolality [10-13]) and genetic engineering (including the overexpression of antiapoptotic proteins such as Bcl-xL, cell cycle-promoting, cyclin-dependent kinase homologs, and endoplasmic reticulum (ER)-resident chaperones [14-16]) have been studied extensively.

Erythropoietin (EPO) is a representative therapeutic glycoprotein that has been manufactured in CHO cells. EPO, a glycoprotein composed of 165 amino acids and a type of hormone mainly produced in adult kidneys, plays a crucial role in stimulating the bone marrow to increase the number of red blood cells (RBCs) [17]. However, if a sufficient amount of EPO is not produced due to kidney injuries or when bone marrow is not stimulated by EPO, anemia can occur because RBCs are poorly produced [18]. Some studies have also shown that EPO is effective in promoting angiogenesis and antiapoptosis of ischemic tissues $[19,20]$. Due to its therapeutic potential, recombinant EPO has been applied in clinical treatments for anemia due to chronic kidney disease and for decreasing the need for RBC transfusions in patients undergoing some types of surgery [21,22]. Many studies have been conducted to improve the yield of EPO production in $\mathrm{CHO}$ cells.

Our previous studies have demonstrated that the productivity of recombinant EPO in $\mathrm{CHO}$ cells can be improved not only by overexpressing the silkworm-derived 30Kc19 gene, but also by supplementing the culture medium with a recombinant $30 \mathrm{Kc} 19$ protein produced in the Escherichia coli (E. coli) expression system [23,24]. 30Kc19 is a type of plasma protein found in silkworm hemolymph and is a member of the structurally related $30 \mathrm{~K}$ protein family. Among 30K proteins, 30Kc19 has both cell-penetrating and proteinstabilizing properties $[25,26]$. These findings suggest that the enhanced EPO productivity in recombinant $\mathrm{CHO}$ cells after the intracellular delivery of the $30 \mathrm{Kc} 19$ protein is due to the stabilization of mitochondrial enzyme complexes responsible for electron transport and ATP generation [27]. Meanwhile, other studies have demonstrated that the $\alpha$-helix N-terminal domain of $30 \mathrm{Kc} 19(30 \mathrm{Kc} 19 \alpha)$, dominantly expressed as a soluble form in E. coli, exhibits protein-stabilizing and cell-penetrating effects similar to or higher than the fulllength $30 \mathrm{Kc} 19$ protein $[28,29]$. However, the effect of the $30 \mathrm{Kc} 19 \alpha$ protein on recombinant protein production in $\mathrm{CHO}$ cells compared to the effect of the full-length $30 \mathrm{Kc} 19$ protein has not yet been reported. Therefore, the objective of this study was to investigate the effect of the $30 \mathrm{Kc} 19 \alpha$ protein on the productivity of recombinant human EPO compared to that of the full-length $30 \mathrm{Kc} 19$ protein after the recombinant $30 \mathrm{Kc} 19 \alpha$ protein was produced in an $E$. coli expression system and added to a $\mathrm{CHO}$ cell culture medium.

\section{Materials and Methods}

\subsection{Plasmid Construction and Production of Recombinant Protein in E. coli Expression System}

The 30Kc19 $\alpha$ and 30Kc19 genes were cloned and inserted into a pET-23a expression plasmid vector (Novagen, Madison, WI, USA) using the EcoRI and XhoI restriction enzyme sites, respectively, as described in previous studies [24,28]. The E. coli BL21 strain (DE3, Enzynomics, Daejeon, Korea) was then transformed with the recombinant plasmid and cultivated exponentially in Luria-Bertani (LB) broth medium until O.D.600nm reached 0.6. It was then incubated with $1 \mathrm{mM}$ of isopropyl- $\beta$-D-thiogalactopyranoside (IPTG, Bio Basic Canada Inc., Markham, ON, Canada) for $4 \mathrm{~h}$ at $37^{\circ} \mathrm{C}$. Cells were then collected and sonicated in a resuspension buffer ( $20 \mathrm{mM}$ Tris- $\mathrm{HCl}, 500 \mathrm{mM} \mathrm{NaCl}, 20 \mathrm{mM}$ imidazole, $\mathrm{pH}$ 8.0). After centrifugation at $12,000 \times g$, the supernatant containing each recombinant protein expressed as a soluble form was loaded onto a nickel-charged nitrilotriacetic acid (Ni-NTA) affinity chromatography column (HisTrap HP, Cytiva, Uppsala, Sweden) equipped with an AKTA Start instrument (Cytiva). The column was then eluted with $350 \mathrm{nM}$ imidazolecontaining buffer. Following elution, the purified protein was dialyzed against Dulbecco's Modified Eagle Medium/Nutrient Mixture F-12 basal medium (DMEM/F12, Thermo Fisher Scientific, Waltham, MA, USA) and stored at $-70{ }^{\circ} \mathrm{C}$ until use. The concentration of each recombinant protein was determined using a Pierce ${ }^{\mathrm{TM}}$ BCA protein assay kit (Thermo Fisher Scientific) according to the instructions. 


\subsection{Cell Culture}

In this study, a $\mathrm{CHO}$ cell line was obtained and used to produce recombinant human $\mathrm{EPO}$ (EPO-CHO), as described in previous studies [23,30]. Briefly, exponentially growing cells were seeded into dishes and cultivated for three days in DMEM/F-12 medium supplemented with $10 \%$ fetal bovine serum (FBS, Welgene, Daejeon, Korea), $100 \mathrm{U} / \mathrm{mL}$ penicillin, and $100 \mu \mathrm{g} / \mathrm{mL}$ streptomycin (complete medium) at $37{ }^{\circ} \mathrm{C}$ in a $5 \% \mathrm{CO}_{2}$-humidified incubator (BB15, Thermo Fisher Scientific). The medium was then replaced with FBS-free DMEM/F12 and further incubated for the production of EPO. Viable cell density and viability were determined using a hemocytometer. Dead cells were distinguished from viable cells by staining with Trypan blue dye (Thermo Fisher Scientific).

\subsection{EPO Production from $\mathrm{CHO}$ Cells}

EPO-CHO cells were seeded in 6-well plates (SPL Life Science, Pocheon, Korea) at a density of $2 \times 10^{4}$ cells $/ \mathrm{cm}^{2}$ and incubated at $37^{\circ} \mathrm{C}$ for $48 \mathrm{~h}$ in a complete medium. $\mathrm{CHO}$ cells were pre-treated with $30 \mathrm{Kc} 19 \alpha$ and $30 \mathrm{Kc} 19$ proteins in DMEM/F-12 medium containing $10 \%$ FBS for $24 \mathrm{~h}$. After washing with phosphate-buffer saline (PBS) the next day, $\mathrm{CHO}$ cells were treated with $30 \mathrm{Kc} 19 \alpha$ and $30 \mathrm{Kc} 19$ proteins in serum-free DMEM/F12 medium. For EPO production, cells were cultured for 3 days without changing the medium. The medium was centrifuged at $300 \times g$ for $3 \mathrm{~min}$ at $4{ }^{\circ} \mathrm{C}$ to remove cells and the supernatant was stored at $-70{ }^{\circ} \mathrm{C}$ until analysis.

\subsection{Enzyme-Linked Immunosorbent Assay (ELISA)}

The concentration of EPO secreted into the conditioned medium was measured using a LEGEND MAX ${ }^{\mathrm{TM}}$ Human Erythropoietin ELISA Kit (BioLegend, San Diego, CA, USA). The ELISA was performed according to the instructions. Briefly, $50 \mu \mathrm{L}$ of assay buffer was added into a plate provided by the kit. The plate was incubated with $50 \mu \mathrm{L}$ of EPOcontaining samples for $2 \mathrm{~h}$ at room temperature (RT). Following incubation with $100 \mu \mathrm{L}$ biotinylated EPO antibody solution for $2 \mathrm{~h}$ and $100 \mu \mathrm{L}$ of the avidin-conjugated horseradish peroxidase solution for $30 \mathrm{~min}$ sequentially at $\mathrm{RT}$, the plate was further incubated with $100 \mu \mathrm{L}$ of the substrate solution for $15 \mathrm{~min}$ at RT. After stopping the colorimetric reaction, absorbance at $450 \mathrm{~nm}$ was measured using a microplate reader (Multiskan GO, Thermo Fisher Scientific).

\subsection{Immunofluorescence Analysis}

For immunofluorescence analysis, EPO-CHO cells were seeded into a 24-well plate at a density of $2 \times 10^{4}$ cells $/ \mathrm{cm}^{2}$ and cultured with complete medium. The next day, cells were treated with serum-free DMEM/F-12 containing 30Kc19 $\alpha$ or 30Kc19 for $4 \mathrm{~h}$. After fixing with $4 \%$ paraformaldehyde (PFA, Sigma Aldrich, St. Louis, MO, USA) for $15 \mathrm{~min}$, cells were permeabilized with $0.25 \%$ Triton X-100 (Daejeong, Siheung, Korea) in PBS and subsequently blocked with $3 \%$ bovine serum albumin in PBS-T (0.1\% Tween-20 in PBS). Cells were then sequentially incubated with goat anti-T7-tag polyclonal antibody (Abcam, Cambridge, UK) at $4{ }^{\circ} \mathrm{C}$ overnight and donkey anti-goat Alexa Fluor 488-conjugated secondary antibody (Invitrogen, Carlsbad, CA, USA) at RT for $1 \mathrm{~h}$. Following incubation with $1 \mu \mathrm{g} / \mathrm{mL} 4^{\prime}$,6-diamidino-2-phenylindole (DAPI, Sigma Aldrich) for cell nuclei staining, fluorescence images were obtained under a fluorescence microscope (Leica Microsystems, Wetzlar, Germany).

\subsection{Sodium Dodecyl Sulfate-Polyacrylamide Gel Electrophoresis (SDS-PAGE) and Immunoblot Analysis}

Protein samples were mixed with SDS-PAGE loading buffer containing SDS and $\beta$ mercaptoethanol (LPS solution, Daejeon, Korea), and were denatured by boiling. Then, the samples were electrophoretically separated using $15 \%$ sodium dodecyl sulfatepolyacrylamide gels in a reducing condition. These separated proteins were visualized by Coomassie Brilliant Blue staining (Sigma Aldrich). For immunoblot analysis, protein 
samples were separated by SDS-PAGE and subsequently transferred to a polyvinylidene fluoride membrane (Bio-Rad, Hercules, CA, USA). After blocking with 5\% skim milk in TBS-T ( $0.1 \%$ Tween-20 in Tris-buffered saline), the membrane was sequentially incubated with mouse anti-human EPO monoclonal antibody (Santa Cruz Biotechnology, Dallas, TX, USA) at $4{ }^{\circ} \mathrm{C}$ overnight and horseradish peroxidase-conjugated goat anti-mouse IgG antibody (Thermo Fisher Scientific) at RT for $1 \mathrm{~h}$. Between every step, the membrane was washed four times with TBS-T ( 5 min per wash). Finally, target protein bands were visualized using Amersham ECL ${ }^{\mathrm{TM}}$ Prime Western Blotting Detection Reagent and Amersham Hyperfilm ECL (Cytiva).

\subsection{NADPH/NADP ${ }^{+}$Quantitative Assay}

An NADPH/NADP ${ }^{+}$assay was performed using an NADP/NADPH Assay Kit (Abcam) according to the manufacturer's instructions. Briefly, approximately $4 \times 10^{6}$ cells were suspended in $800 \mu \mathrm{L}$ of NADP/NADPH extraction buffer and lysed by two freeze/thaw cycles. For the total $\mathrm{NADP}^{+}$and NADPH measurements, following the conversion of $\mathrm{NADP}^{+}$to NADPH and the subsequent NADPH developing step in an enzyme cycling reaction, the absorbance was measured at $450 \mathrm{~nm}$ using a microplate reader (Multiskan GO, Thermo Fisher Scientific). For the NADPH measurement, samples were heated at $60^{\circ} \mathrm{C}$ for $30 \mathrm{~min}$ to decompose all NADP and cooled on ice. Then, the enzyme reaction mix was added to convert $\mathrm{NADP}^{+}$to NADPH.

\subsection{Statistical Analysis}

All values are written as the mean \pm standard deviation. All quantitative data were obtained from triplicate samples in experiments that were performed several times. Statistical significance was determined with Student's $t$-test and $p<0.05$ was considered statistically significant.

\section{Results and Discussion}

\subsection{Kc19 $\alpha$ Protein Expression and Its Intracellular Delivery}

First, we produced 30Kc19 $\alpha$ and full-length $30 \mathrm{Kc} 19$ proteins in soluble form in an E. coli expression system. Recombinant plasmids were designed to express target proteins with a T7-tag at the N-terminus and a $6 \times$ histidine tag at the $\mathrm{C}$-terminus (Figure 1a). Theoretical molecular weights (MWs) of 30Kc19 $\alpha$ and 30Kc19, including said tags, are about $13 \mathrm{kDa}$ and $30 \mathrm{kDa}$, respectively. Western blot and SDS-PAGE analyses for soluble cell lysates revealed that $30 \mathrm{Kc} 19 \alpha$, like $30 \mathrm{Kc} 19$, as demonstrated in our previous study [28], was successfully expressed as a soluble form (Figure 1b,c). To compare the production yield, we repeated large-scale productions (4 L culture scale) for $30 \mathrm{Kc} 19 \alpha$ and $30 \mathrm{Kc} 19$ twice. Although production yields per unit culture scale for finally purified $30 \mathrm{kc} 19 \alpha$ and $30 \mathrm{Kc} 19$ were different $(23.35 \pm 2.51 \mathrm{mg} / \mathrm{L}$ and $47.43 \pm 8.53 \mathrm{mg} / \mathrm{L}$, respectively), the molar productivity of $30 \mathrm{kc} 19 \alpha$ was similar to that of $30 \mathrm{Kc} 19$ when it was converted into moles in consideration of the MW difference between the two proteins (Figure 1d). According to results of predicting the solubility of 30kc19 $\alpha$ and 30Kc19 from amino acid sequences using a web-based tool [31], the solubility of 30kc19 $\alpha$ was significantly higher than that of 30Kc19 ( 0.836 vs. 0.547). This implies that $30 \mathrm{kc} 19 \alpha$ might exhibit a higher soluble expression than $30 \mathrm{Kc} 19$ in an E. coli expression system. However, no significant difference in molar productivity between $30 \mathrm{kc} 19 \alpha$ (a part of 30Kc19) and the full-length 30Kc19 protein was observed as shown in this study. This might be due to the lack of optimization in the recombinant protein production using the E. coli expression system. Further studies on various factors related to $30 k c 19 \alpha$ expression, such as medium composition, $\mathrm{pH}$, dissolved oxygen control, temperature, duration of culture, and so forth, are needed to achieve a precise comparison of the productivity of 30kc19 $\alpha$ and $30 \mathrm{Kc} 19$ in an E. coli expression system. 
(a)

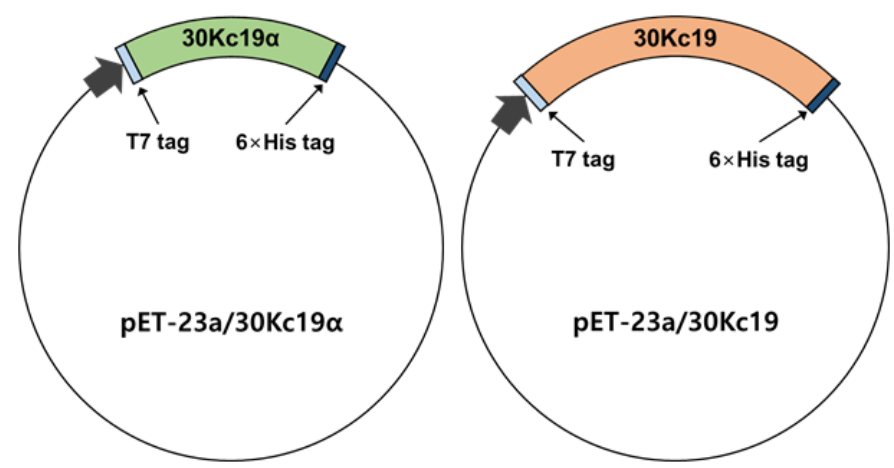

(c)

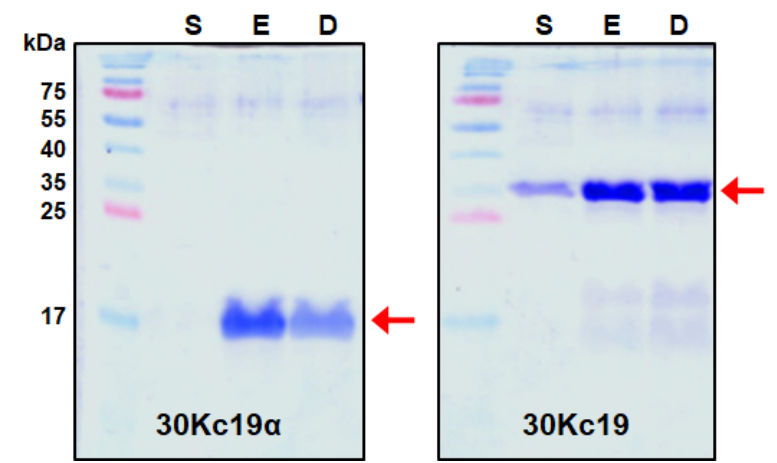

(b)

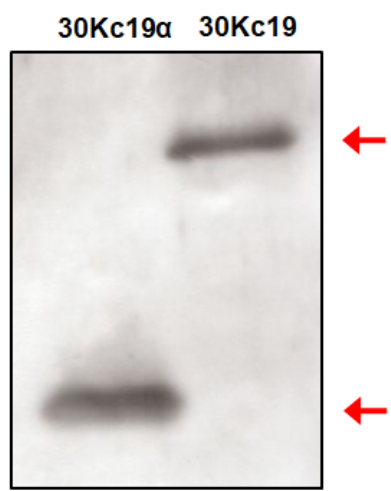

(d)

\begin{tabular}{ccc}
\hline & 30Kc19 $\alpha$ & $30 \mathrm{Kc19}$ \\
\hline Yield & $23.35 \pm 2.51 \mathrm{mg} / \mathrm{L}$ & $47.43 \pm 8.53 \mathrm{mg} / \mathrm{L}$ \\
Molar productivity & 1.07 & 1 \\
\hline
\end{tabular}

Figure 1. Construction of recombinant $30 \mathrm{Kc} 19 \alpha$ and its expression in E. coli in comparison with 30Kc19: (a) construction of E. coli expression vectors pET-23a/30Kc19 $\alpha$ and pET-23a/30Kc19; (b) Western blot results; (c) sodium dodecyl sulfate-polyacrylamide gel electrophoresis (SDS-PAGE) of 30Kc19 $\alpha$ and 30Kc19 expressed in soluble form. M, protein maker; S, soluble cell lysate; E, proteins eluted from Ni-NTA affinity chromatography column; D, finally dialyzed protein; (d) comparison of production yields of 30Kc19 $\alpha$ and 30Kc19 after chromatography-mediated purification and dialysis.

Next, to determine whether $30 \mathrm{kc} 19 \alpha$ could penetrate into EPO-CHO cells, cells were treated with $30 \mathrm{kc} 19 \alpha$ for $4 \mathrm{~h}$. It has been revealed that the ability of $30 \mathrm{Kc} 19 \alpha$ to deliver cargo proteins into cells is a little higher than that of 30Kc19 [28]. The results of the immunofluorescence analysis revealed that the intracellularly delivered $30 \mathrm{Kc} 19 \alpha$ was detected as expected. However, there was no significant difference in the cell-penetrating abilities between $30 \mathrm{Kc} 19 \alpha$ and $30 \mathrm{Kc} 19$ (Figure 2). Such similar cell-penetrating abilities of $30 \mathrm{Kc} 19 \alpha$ and $30 \mathrm{Kc} 19$ shown above might be due to the non-quantitative nature of immunofluorescence analysis.

\subsection{Effect of $30 \mathrm{Kc} 19 \alpha$ on Cell Growth and Viability}

EPO-CHO cells were seeded into 6-well culture plates and incubated with a serumcontaining complete medium for $48 \mathrm{~h}$. Then, EPO-CHO cells were treated with $30 \mathrm{Kc} 19 \alpha$ in the complete medium for a further $24 \mathrm{~h}$. To explore the effect of $30 \mathrm{Kc} 19 \alpha$ on the growth and viability of EPO-CHO cells in a serum-free culture condition, the medium was replaced with serum-free DMEM/F12 containing the same concentration of $30 \mathrm{Kc} 19 \alpha$. During incubation with a complete medium-containing serum, the viability of cells was maintained at over $95 \%$ and the percentage of viable cells increased exponentially. However, after the medium was changed to serum-free DMEM/F12, the rate of viable cell growth gradually decreased. Subsequently, the percentage of viable cells started to decrease. Our previous studies have demonstrated that the addition of the recombinant 30Kc19 protein $(6.5 \mu \mathrm{M})$ or the expression of the $30 \mathrm{Kc} 19$ gene has no impact on the viability or the percentage of viable EPO-CHO cells in a serum-free culture [23,24]. As in the case of $30 \mathrm{Kc} 19$, significant alterations in viability and viable cell concentration were not observed when $30 \mathrm{Kc} 19 \alpha$ up to $16 \mu \mathrm{M}$ was added to the medium (Figure 3 and Supplement Table S1). 
These results indicate that, similar to the full-length $30 \mathrm{Kc} 19,30 \mathrm{Kc} 19 \alpha$ has no ability to regulate the intracellular apoptotic pathway induced by serum deprivation.

\subsection{Improvement of EPO Production}

We then investigated the effect of the $30 \mathrm{Kc} 19 \alpha$ protein on EPO production in $\mathrm{CHO}$ cells. EPO-CHO cells were treated with $30 \mathrm{Kc} 19 \alpha$ under the following three conditions based on the date of medium replacement with serum-free DMEM/F12: pretreatment, cotreatment, and dual treatment. For pretreatment, $30 \mathrm{Kc} 19 \alpha$ was added to the complete medium at day 2 after inoculation and cells were incubated for $24 \mathrm{~h}$. The medium was then replaced with serum-free DMEM/F12. For cotreatment, the medium was replaced with a fresh complete medium on day 2 after inoculation followed by serum-free DMEM/F12 containing $30 \mathrm{Kc} 19 \alpha$ on day 3. Cells were further incubated for 3 days (Figure 4a). As a result, although supplementation with $16 \mu \mathrm{M} 30 \mathrm{Kc} 19 \alpha$ resulted in a certain enhancement of EPO production in both cases, the extent of such an enhancement was not statistically significant (Figure $4 \mathrm{~b}$ ). Next, we combined to pretreatment and cotreatment protocol for dual treatment. In this condition, cells were treated with $30 \mathrm{Kc} 19 \alpha$ once in complete medium for $24 \mathrm{~h}$ and then again in serum-free DMEM/F12 for 3 days. The results show that the cumulative EPO production in serum-free DMEM/F12 for 3 days was increased nearly three times in cells treated dually with $16 \mu \mathrm{M} 30 \mathrm{Kc} 19 \alpha$ compared to that in the nontreated control (Figure 4c).
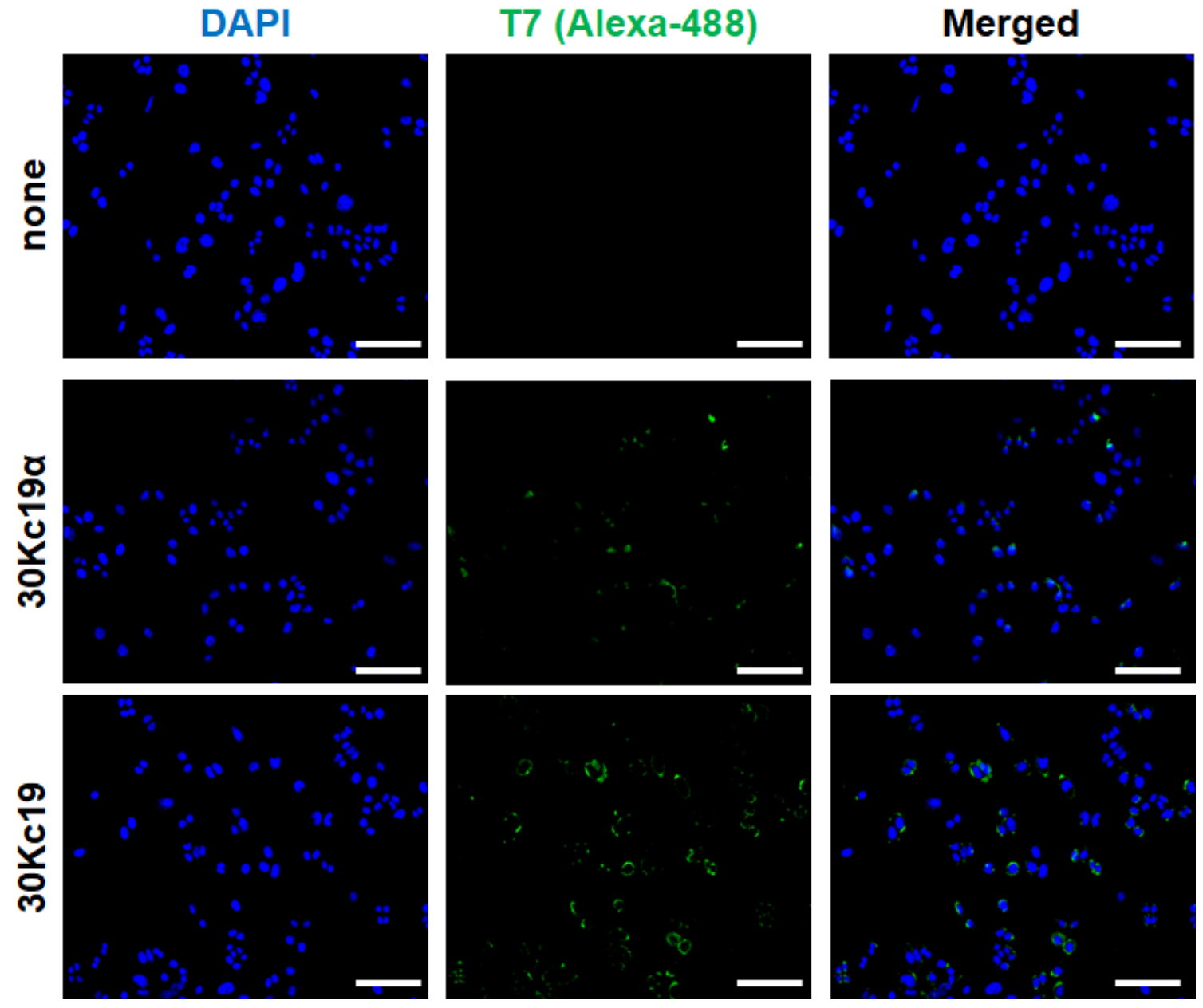

Figure 2. Intracellular delivery of recombinant $30 \mathrm{Kc} 19 \alpha$ protein into EPO-CHO cells. EPO-CHO cells were treated with $16 \mu \mathrm{M} 30 \mathrm{Kc} 19 \alpha$ for $4 \mathrm{~h}$ in a complete medium. Intracellularly delivered 30Kc19 $\alpha$ was then visualized by immunofluorescence analysis using anti-T7 tag primary antibody and Alexa Fluor 488-conjugated secondary antibody (green). The cellpenetrating property of $30 \mathrm{Kc} 19 \alpha$ was compared to that of full-length $30 \mathrm{Kc} 19$. Cell nucleus was stained by DAPI (blue). Scale bar, $100 \mu \mathrm{m}$. 
(a)

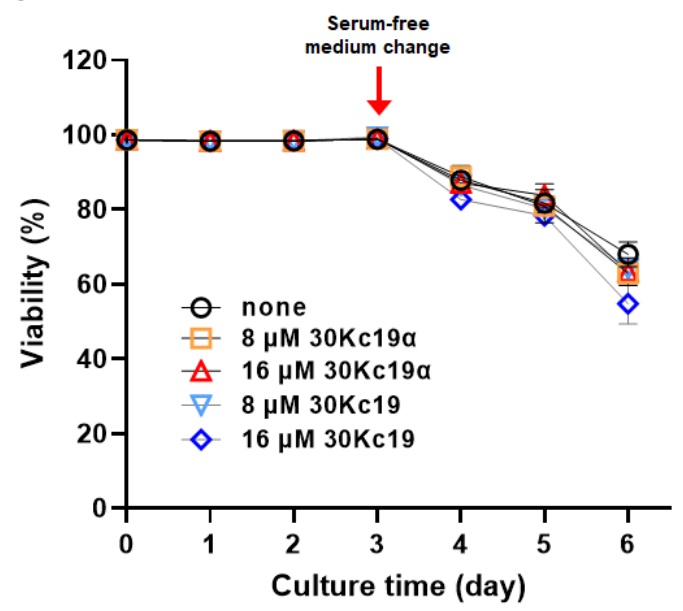

(b)

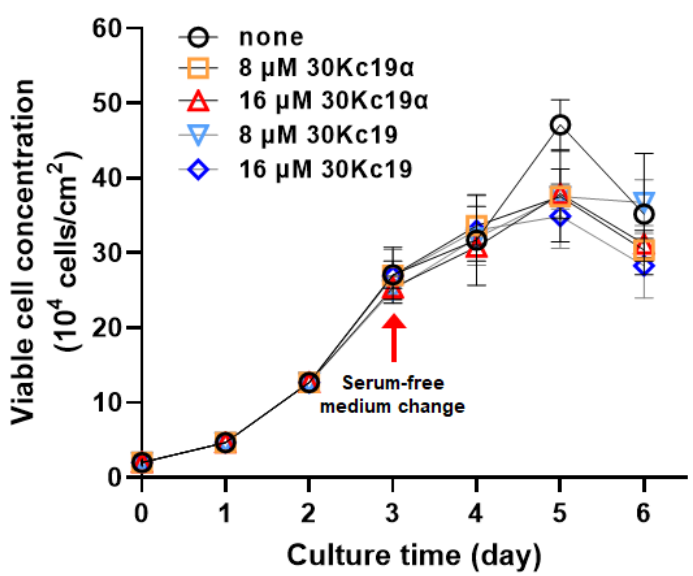

Figure 3. Effect of $30 \mathrm{Kc} 19 \alpha$ on viability and viable cell growth of $\mathrm{CHO}$ cells. After $48 \mathrm{~h}$ of incubation in a complete medium, EPO-CHO cells were treated with the indicated concentration of 30Kc19 $\alpha$ or 30Kc19 for a further $24 \mathrm{~h}$ in fresh complete medium. The medium was replaced with serum-free DMEM/F12 containing each protein. (a) Cell viability and (b) viable cell concentration of EPO-CHO cells before and after the medium change. Error bars indicate standard deviations ( $n=3$ per group).

(a)

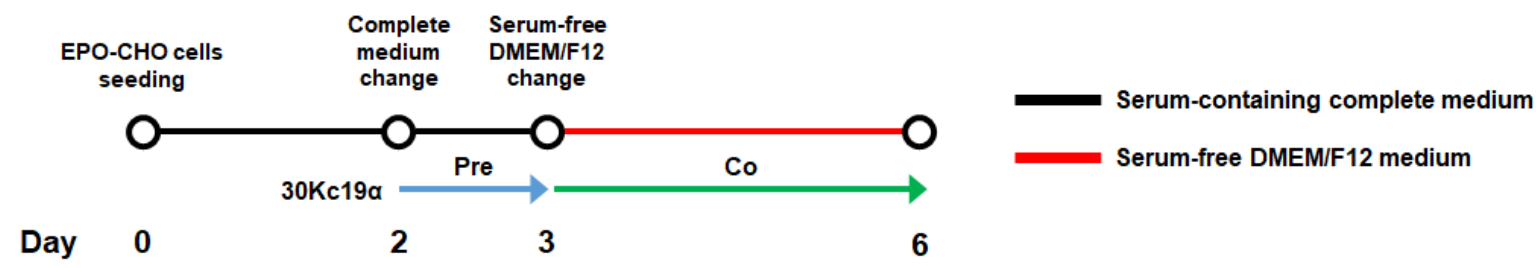

(b)

Pre

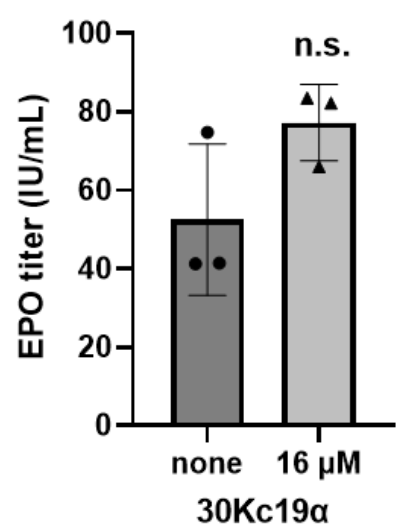

Co

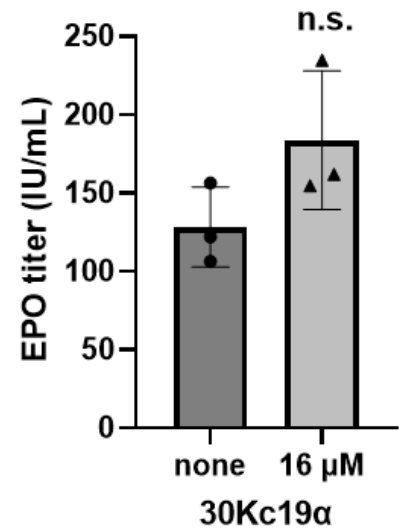

(c)

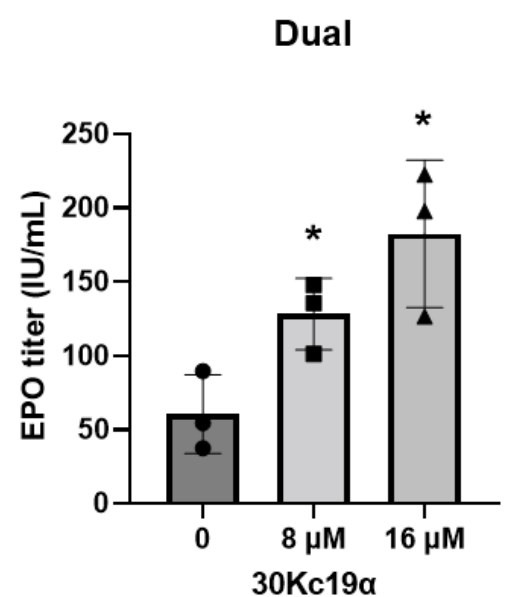

Figure 4. Effects of $30 \mathrm{Kc} 19 \alpha$ treatments on rhEPO production in $\mathrm{CHO}$ cells. (a) Schedule for the treatment with $30 \mathrm{Kc} 19 \alpha$ of EPO-CHO cells. Conditioned media of cell cultures treated (b) once (pretreated and cotreated) and (c) twice (dually treated) with $30 \mathrm{Kc} 19 \alpha$ were collected on day 3 of culture in serum-free medium. Titers of rhEPO were determined with an enzyme-linked immunosorbent assay (ELISA). Error bars indicate standard deviations ( $n=3$ per group). Statistical significance was determined using Student's $t$-test. ${ }^{*}, p<0.05$; n.s., not significant compared to the nontreated control. 
Based on the previous study showing that EPO production in $\mathrm{CHO}$ cells can be enhanced by treatment with the recombinant $30 \mathrm{Kc} 19$ protein [24], the effects of 30Kc19 $\alpha$ and the $30 \mathrm{Kc} 19$ protein on EPO production were compared. As a result of the dual treatment, while the EPO production was increased by $30 \mathrm{Kc} 19 \alpha$ treatment in a dosedependent manner, it showed no significant differences between cells treated with $30 \mathrm{Kc} 19 \alpha$ at $16 \mu \mathrm{M}$ and cells treated with $30 \mathrm{Kc} 19$ at the same concentration $(16 \mu \mathrm{M})$ (Figure 5). These results demonstrate that $30 \mathrm{Kc} 19 \alpha$, which is a truncated form of $30 \mathrm{Kc} 19$, has the same function as the full-length $30 \mathrm{Kc} 19$. Both can be intracellularly delivered to improve EPO production in CHO cells. Nevertheless, $30 \mathrm{Kc} 19 \alpha$ is considered advantageous as a medium supplement over the full-length $30 \mathrm{Kc} 19$ due to its physicochemical characteristics. If various tags are not included, the theoretical MW and isoelectric point (pI) of full-length $30 \mathrm{Kc} 19$ are about $27 \mathrm{kDa}$ and 6.60 , respectively, while those of 30Kc19 $\alpha$ are about $11 \mathrm{kDa}$ and 4.73 , respectively. Most EPO biopharmaceuticals such as EPOGEN ${ }^{\circledR}$ have MWs in the range of 30 to $35 \mathrm{kDa}$, which is not significantly different from that of $30 \mathrm{Kc} 19$, making it difficult to separate them if the purification process is performed through size exclusion chromatography (SEC). On the other hand, the significant size difference between $30 \mathrm{Kc} 19 \alpha$ and EPO may facilitate the purification process through SEC. In addition to the case of $\mathrm{EPO}, 30 \mathrm{Kc} 19 \alpha$ may be beneficial for the manufacture of therapeutic monoclonal antibodies (mAbs) because it has larger differences than the full-length 30Kc19 compared to mAbs with MWs and pI values of approximately $150 \mathrm{kDa}$ and in the range of 8 to 9 , respectively. In particular, it is believed that the large $\mathrm{pI}$ value difference can facilitate the separation of mAbs from $30 \mathrm{Kc} 19 \alpha$ used as a medium supplement by ion exchange chromatography.

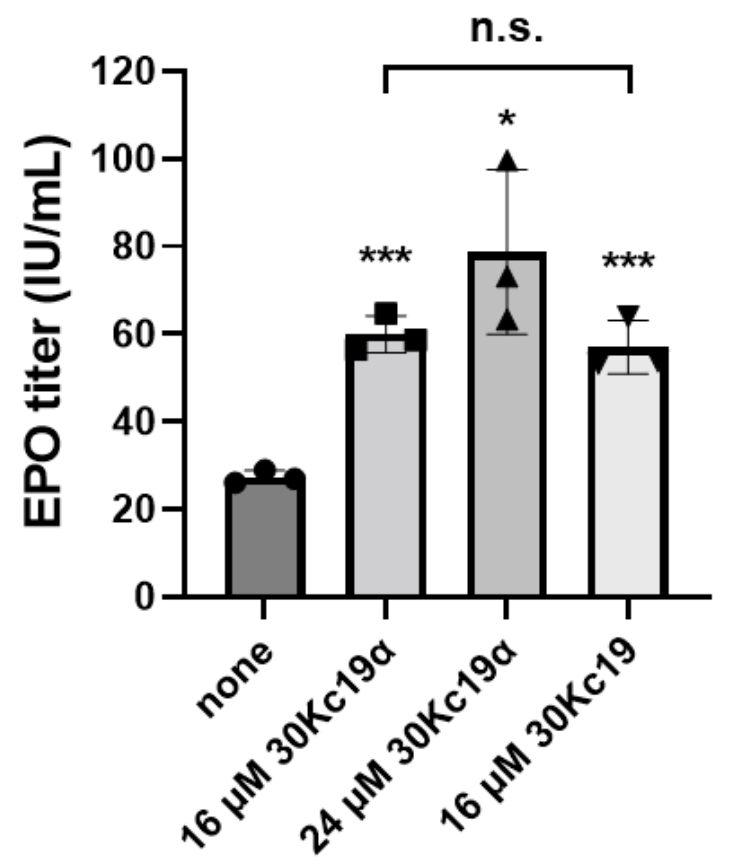

Figure 5. Comparison of effects of $30 \mathrm{Kc} 19 \alpha$ and full-length $30 \mathrm{Kc} 19$ on rhEPO production in $\mathrm{CHO}$ cells. Cells were dually treated with the indicated concentration of $30 \mathrm{Kc} 19 \alpha$ or $30 \mathrm{Kc} 19$, respectively. Subsequently, the conditioned media were collected on day 2 of culture in serum-free medium. Titers of rhEPO were determined by ELISA. Error bars indicate standard deviations ( $n=3$ per group). Statistical significance was determined using Student's $t$-test. ${ }^{*}, p<0.05 ;{ }^{* * *}, p<0.005$ compared to the nontreated control; n.s., not significant in comparison between 30Kc19 $\alpha$ and 30Kc19-treated group.

\subsection{Effect of $30 \mathrm{Kc} 19 \alpha$ on NADPH/NADP ${ }^{+}$Ratio of EPO-CHO Cells}

Nicotinamide adenine dinucleotide phosphate (NADPH), as a coenzyme, is a substrate for several metabolic redox reactions. It is known that NADPH plays a central role in a variety of biosynthetic pathways such as nucleic acid metabolism and protein synthesis [32-34]. In addition, the intracellular NADPH/NADP ${ }^{+}$(oxidized form of NADPH) ratio is respon- 
sible for the detoxification of reactive oxygen species (ROS) by maintaining appropriate reduced/oxidized glutathione (GSH/GSSG) $[35,36]$. As a result of comparing EPO-CHO cells treated dually with $24 \mu \mathrm{M}$ of $30 \mathrm{Kc} 19 \alpha$ to those in the nontreated control group, the intracellular NADPH/NADP ${ }^{+}$ratio was significantly increased by the $30 \mathrm{Kc} 19 \alpha$ treatment (Figure 6). Our previous studies have demonstrated that mitochondrial membrane potential and adenosine triphosphate (ATP) generation can be enhanced by the addition of the recombinant 30Kc19 protein as well as by the overexpression of the 30Kc19 gene [24]. Such enhancements are due to the stabilizing effect of $30 \mathrm{Kc} 19$ on intracellular enzymes involved in the mitochondrial electron transport system [27]. Likewise, intracellularly delivered $30 \mathrm{Kc} 19 \alpha$ might have affected the activities (or stabilities) of several enzymes related to the flux of reducing power from cytosol to mitochondria, leading to the enhancement of the $\mathrm{NADPH} / \mathrm{NADP}^{+}$ratio and the subsequent recombinant EPO biosynthesis.

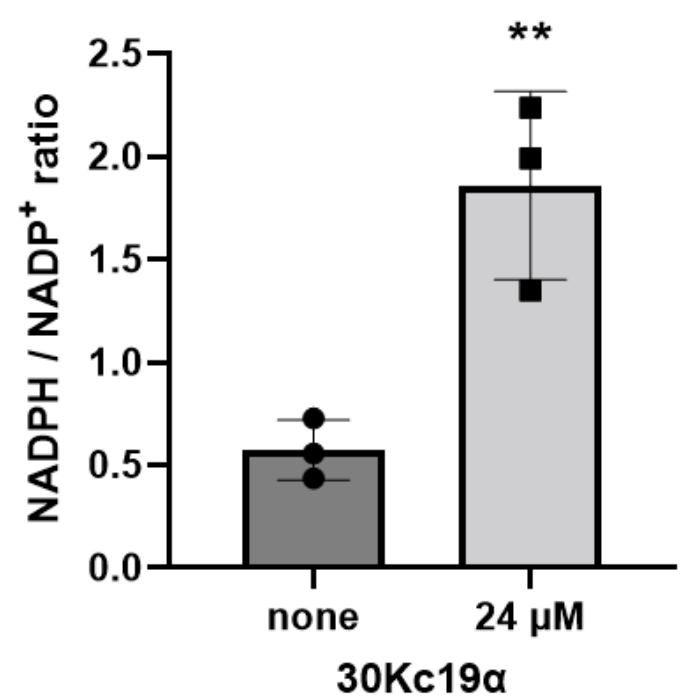

Figure 6. Increase in intracellular NADPH $/ \mathrm{NADP}^{+}$ratio by treatment with $30 \mathrm{Kc} 19 \alpha$. EPO-CHO cells were dually treated with $24 \mu \mathrm{M} 30 \mathrm{Kc} 19 \alpha$, and subsequently collected on day 3 of culture in serum-free medium. The concentration of intracellular NADPH and $\mathrm{NADP}^{+}$were determined using an NADP/NADPH assay kit. Error bars indicate standard deviations ( $n=3$ per group). Statistical significance was determined between nontreated control and 30Kc19 $\alpha$-treated cells using Student's $t$-test. ${ }^{* *}, p<0.01$ compared to the non-treated control.

\section{Conclusions}

The results of this study demonstrate that $30 \mathrm{Kc} 19 \alpha$, a truncated form of the $30 \mathrm{Kc} 19$ protein, exhibits similar cell-penetrating and protein expression-enhancing properties to those of the full-length $30 \mathrm{Kc} 19$ protein. Due to these multifunctional properties, the production of recombinant $\mathrm{EPO}$ in $\mathrm{CHO}$ cells was significantly improved when the culture medium was supplemented with the $30 \mathrm{Kc} 19 \alpha$ protein. Although there were no significant differences in the promoting effects on EPO production between $30 \mathrm{Kc} 19 \alpha$ and $30 \mathrm{Kc} 19$, $30 \mathrm{Kc} 19 \alpha$ might have advantages for the downstream purification process of therapeutic biopharmaceuticals, including EPO and mAbs, due to its physicochemical characteristics such as a smaller size and lower $\mathrm{pI}$ value than the full-length $30 \mathrm{Kc} 19$. Thus, $30 \mathrm{Kc} 19 \alpha$ could be a promising medium supplement for enhancing therapeutic protein productivities in an industrial mammalian cell culture.

Supplementary Materials: The following are available online at https:/ /www.mdpi.com/article/10 $.3390 /$ app $112211009 /$ s1, Table S1: Effect of 30Kc19 $\alpha$ on viability and viable cell growth of CHO cells after replacement with serum-free medium. 
Author Contributions: H.C. collected data and evidence. J.-H.P. conceived and designed the study. H.C. and J.-H.P. wrote the manuscript. H.C. and J.-H.P. drew the figures. J.-H.P. directed and validated the data analysis. All authors have read and agreed to the published version of the manuscript.

Funding: This research was supported by the Basic Science Research Program of the National Research Foundation (NRF) funded by the Korean Government (Ministry of Science and ICT) (No. 2020R1A4A1016093 and 2021R1A2C1010865).

Institutional Review Board Statement: Not applicable.

Informed Consent Statement: Not applicable.

Conflicts of Interest: The authors declare no conflict of interest.

\section{References}

1. Johnson, I.S. Human insulin from recombinant DNA technology. Science 1983, 219, 632-637. [CrossRef]

2. Kesik-Brodacka, M. Progress in biopharmaceutical development. Biotechnol. Appl. Biochem. 2018, 65, 306-322. [CrossRef] [PubMed]

3. Pavlou, A.K.; Reichert, J.M. Recombinant protein therapeutics—success rates, market trends and values to 2010. Nat. Biotechnol. 2004, 22, 1513-1519. [CrossRef]

4. Wurm, F.M. Production of recombinant protein therapeutics in cultivated mammalian cells. Nat. Biotechnol. 2004, 22, 1393-1398. [CrossRef] [PubMed]

5. Omasa, T.; Onitsuka, M.; Kim, W.-D. Cell engineering and cultivation of Chinese hamster ovary (CHO) cells. Curr. Pharm. Biotechnol. 2010, 11, 233-240. [CrossRef] [PubMed]

6. Kim, J.Y.; Kim, Y.-G.; Lee, G.M. CHO cells in biotechnology for production of recombinant proteins: Current state and further potential. Appl. Microbiol. Biotechnol. 2012, 93, 917-930. [CrossRef] [PubMed]

7. Hossler, P.; Khattak, S.F.; Li, Z.J. Optimal and consistent protein glycosylation in mammalian cell culture. Glycobiology 2009, 19, 936-949. [CrossRef] [PubMed]

8. Datta, P.; Linhardt, R.J.; Sharfstein, S.T. An'omics approach towards CHO cell engineering. Biotechnol. Bioeng. 2013, 110, $1255-1271$. [CrossRef] [PubMed]

9. Ohtsubo, K.; Marth, J.D. Glycosylation in cellular mechanisms of health and disease. Cell 2006, 126, 855-867. [CrossRef]

10. Yoon, S.K.; Song, J.Y.; Lee, G.M. Effect of low culture temperature on specific productivity, transcription level, and heterogeneity of erythropoietin in Chinese hamster ovary cells. Biotechnol. Bioeng. 2003, 82, 289-298. [CrossRef]

11. Yoon, S.K.; Choi, S.L.; Song, J.Y.; Lee, G.M. Effect of culture pH on erythropoietin production by Chinese hamster ovary cells grown in suspension at 32.5 and $37.0^{\circ} \mathrm{C}$. Biotechnol. Bioeng. 2005, 89, 345-356. [CrossRef]

12. Restelli, V.; Wang, M.D.; Huzel, N.; Ethier, M.; Perreault, H.; Butler, M. The effect of dissolved oxygen on the production and the glycosylation profile of recombinant human erythropoietin produced from CHO cells. Biotechnol. Bioeng. 2006, 94, 481-494. [CrossRef] [PubMed]

13. Ryu, J.S.; Kim, T.K.; Chung, J.Y.; Lee, G.M. Osmoprotective effect of glycine betaine on foreign protein production in hyperosmotic recombinant Chinese hamster ovary cell cultures differs among cell lines. Biotechnol. Bioeng. 2000, 70, 167-175. [CrossRef]

14. Chiang, G.G.; Sisk, W.P. Bcl-xl mediates increased production of humanized monoclonal antibodies in Chinese hamster ovary cells. Biotechnol. Bioeng. 2005, 91, 779-792. [CrossRef]

15. Jaluria, P.; Betenbaugh, M.; Konstantopoulos, K.; Shiloach, J. Enhancement of cell proliferation in various mammalian cell lines by gene insertion of a cyclin-dependent kinase homolog. BMC Biotechnol. 2007, 7, 71. [CrossRef]

16. Hwang, S.O.; Chung, J.Y.; Lee, G.M. Effect of doxycycline-regulated ERp57 expression on specific thrombopoietin productivity of recombinant CHO cells. Biotechnol. Prog. 2003, 19, 179-184. [CrossRef]

17. Jelkmann, W. Physiology and pharmacology of erythropoietin. Transfus. Med. Hemother. 2013, 40, 302-309. [CrossRef]

18. Moore, E.; Bellomo, R. Erythropoietin (EPO) in acute kidney injury. Ann. Intensive Care 2011, 1, 3. [CrossRef]

19. Ji, Y.Q.; Zhang, Y.Q.; Li, M.Q.; Du, M.R.; Wei, W.W.; Li, D.J. EPO improves the proliferation and inhibits apoptosis of trophoblast and decidual stromal cells through activating STAT-5 and inactivating p38 signal in human early pregnancy. Int. J. Clin. Exp. Pathol. 2011, 4, 765-774. [PubMed]

20. Sun, C.; Zhang, S.; Wang, J.; Jiang, W.; Xin, Q.; Chen, X.; Zhang, Z.; Luan, Y. EPO enhances the protective effects of MSCs in experimental hyperoxia-induced neonatal mice by promoting angiogenesis. Aging 2019, 11, 2477-2487. [CrossRef]

21. Lee, J.S.; Ha, T.K.; Lee, S.J.; Lee, G.M. Current state and perspectives on erythropoietin production. Appl. Microbiol. Biotechnol. 2012, 95, 1405-1416. [CrossRef]

22. Cazzola, M.; Mercuriali, F.; Brugnara, C. Use of recombinant human erythropoietin outside the setting of uremia. Blood 1997, 89, 4248-4267. [CrossRef]

23. Wang, Z.; Park, J.H.; Park, H.H.; Tan, W.; Park, T.H. Enhancement of recombinant human EPO production and sialylation in Chinese hamster ovary cells through bombyx mori 30Kc19 gene expression. Biotechnol. Bioeng. 2011, 108, 1634-1642. [CrossRef] [PubMed] 
24. Park, J.H.; Wang, Z.; Jeong, H.-J.; Park, H.H.; Kim, B.-G.; Tan, W.-S.; Choi, S.S.; Park, T.H. Enhancement of recombinant human EPO production and glycosylation in serum-free suspension culture of $\mathrm{CHO}$ cells through expression and supplementation of 30Kc19. Appl. Microbiol. Biotechnol. 2012, 96, 671-683. [CrossRef]

25. Park, J.H.; Lee, J.H.; Park, H.H.; Rhee, W.J.; Choi, S.S.; Park, T.H. A protein delivery system using 30 Kc19 cell-penetrating protein originating from silkworm. Biomaterials 2012, 33, 9127-9134. [CrossRef]

26. Park, J.H.; Park, H.H.; Choi, S.S.; Park, T.H. Stabilization of enzymes by the recombinant 30Kc19 protein. Process. Biochem. 2012, 47, 164-169. [CrossRef]

27. Park, J.H.; Lee, H.J.; Park, H.H.; Rhee, W.J.; Park, T.H. Stabilization of cellular mitochondrial enzyme complex and sialyltransferase activity through supplementation of 30Kc19 protein. Appl. Microbiol. Biotechnol. 2015, 99, 2155-2163. [CrossRef]

28. Ryu, J.; Kim, H.; Park, H.H.; Lee, H.J.; Park, J.H.; Rhee, W.J.; Park, T.H. Protein-stabilizing and cell-penetrating properties of $\alpha$-helix domain of 30Kc19 protein. Biotechnol. J. 2016, 11, 1443-1451. [CrossRef]

29. Lee, H.; Kim, S.H.L.; Yoon, H.; Ryu, J.; Park, H.H.; Hwang, N.S.; Park, T.H. Intracellular delivery of recombinant RUNX2 facilitated by cell-penetrating protein for the osteogenic differentiation of hMSCs. ACS Biomater. Sci. Eng. 2020, 6, 5202-5214. [CrossRef] [PubMed]

30. Park, H.H.; Choi, J.; Lee, H.J.; Ryu, J.; Park, J.H.; Rhee, W.J.; Park, T.H. Enhancement of human erythropoietin production in Chinese hamster ovary cells through supplementation of 30Kc19-30Kc6 fusion protein. Process. Biochem. 2015, 50, 973-980. [CrossRef]

31. Hebditch, M.; Carballo-Amador, M.A.; Charonis, S.; Curtis, R.; Warwicker, J. Protein-sol: A web tool for predicting protein solubility from sequence. Bioinformatics 2017, 33, 3098-3100. [CrossRef]

32. Yang, C.S.; Zhang, J.; Zhang, L.; Huang, J.; Wang, Y. Mechanisms of body weight reduction and metabolic syndrome alleviation by tea. Mol. Nutr. Food Res. 2016, 60, 160-174. [CrossRef]

33. Kan, B.; London, I.; Levin, D. Role of reversing factor in the inhibition of protein synthesis initiation by oxidized glutathione. J. Biol. Chem. 1988, 263, 15652-15656. [CrossRef]

34. Rufino-Palomares, E.E.; Reyes-Zurita, F.J.; García-Salguero, L.; Peragón, J.; de la Higuera, M.; Lupiáñez, J.A. NADPH production, a growth marker, is stimulated by maslinic acid in gilthead sea bream by increased NADP-IDH and ME expression. Comp. Biochem. Physiol. C Toxicol. Pharmacol. 2016, 187, 32-42. [CrossRef]

35. Circu, M.L.; Aw, T.Y. Reactive oxygen species, cellular redox systems, and apoptosis. Free Radic. Biol. Med. 2010, 48, 749-762. [CrossRef]

36. Itsumi, M.; Inoue, S.; Elia, A.; Murakami, K.; Sasaki, M.; Lind, E.; Brenner, D.; Harris, I.; Chio, I.; Afzal, S. Idh1 protects murine hepatocytes from endotoxin-induced oxidative stress by regulating the intracellular $\mathrm{NADP}^{+} / \mathrm{NADPH}$ ratio. Cell Death Differ. 2015, 22, 1837-1845. [CrossRef] 